\title{
llegalidade e degradação em Fortaleza: os riscos do conflito entre a agenda urbana e ambiental brasileira ${ }^{1}$
}

\author{
Urban illegality and environmental degradation in Fortaleza: the risks \\ of the conflict between urban and environmental agenda in Brazil
}

Clarissa Figueiredo Sampaio Freitas

Arquiteta, doutora em Arquitetura e Urbanismo (UNB), professora adjunta II do Departamento de Arquitetura e

Urbanismo da Universidade Federal do Ceará (UFC), Fortaleza - CE, e-mail: clarissa@arquitetura.ufc.br

\section{Resumo}

As cidades brasileiras apresentam contrastes no que se refere ao modo de apropriação dos espaços ambientalmente frágeis. Se por um lado, determinados ecossistemas são preservados pelo Estado e apropriados pela iniciativa privada por meio da valorização imobiliária dos terrenos lindeiros, por outro lado, proliferam condições de precariedade urbana e degradação em ecossistemas de grande valor ambiental. O presente trabalho busca relacionar os processos de apropriação da natureza na cidade pelas diversas classes sociais a partir de uma abordagem crítica de determinados dispositivos da legislação ambiental e urbana brasileira. Adota como questão central o papel dos atributos ambientais do território no processo de formação de preços da terra urbana influenciando o potencial de acesso à cidade pela população de baixa renda. Ao desconsiderar essa questão, os dispositivos legais de controle da ocupação do solo apresentam uma compreensão parcial e incompleta da dinâmica socioambiental urbana, sendo incapazes de cumprir seus objetivos de inclusão urbana e/ou proteção ambiental. Por um lado, a política ambiental legitima um padrão de ocupação restritivo que inviabiliza o atendimento da enorme demanda habitacional de baixa renda; por outro lado as políticas urbanas têm aceitado a regularização de assentamentos precários em áreas inadequadas do ponto de vista ambiental, por serem espaços financeiramente viáveis devido à desvalorização relacionada aos atributos ambientais. No sentido de dar suporte à análise proposta, o trabalho estuda um território específico, a Região Metropolitana de Fortaleza, valendo-se de métodos de sobreposição espacial de dados ambientais, socioeconômicos e urbanísticos.

Palavras-chave: Ilegalidade urbana. Degradação ambiental. Fortaleza.

\footnotetext{
1 Uma versão preliminar deste trabalho foi publicada em COUTINHO M.; DA SILVA, R. (Org.). Desafios urbanos para a sustentabilidade ambiental nas cidades brasileiras. Rio de Janeiro: PROURB; UFRJ, 2012. ISBN: 978-85-88027-25-1
} 


\section{Abstract}

Brazilian cities reveal contradictions concerning the development of their environmental sensitive spaces. If, in one hand, private developers appropriate some ecosystems in order to foster real estate profits, on the other hand, the association between urban precariousness and environmental degradation is recurrent. This paper establishes relations between this two contrasting processes of appropriation of ecological sensitive spaces, with a critical perspective about Brazilian urban environmental legislation. It adopts as a central question, the role of environmental attributes in determining real estate prices, influencing the possibility of low-income population in affording the urbanized space. In disregarding such aspect, legal instruments for controlling land development present a partial understanding of urban socio-environmental dynamics, failing to achieve their goals of environmental protection and urban inclusion. In one hand, environmental regulations suggest a restrictive development pattern making it impossible to meet the huge low-income housing demand; on the other hand, the regularization policies accepts the development of environment sensitive ecosystems, because they are the most viable spaces: they tend to have low prices due to their physical attributes. In order to support such line of thought the paper studies a specific territory, Metropolitan Region of Fortaleza, adopting methods of spatial overlay using environmental, socioeconomic and urban data.

Keywords: Urban Illegality. Environmental Degradation. Fortaleza.

No contexto da urbanização dos países periféricos, tem sido recorrente uma dinâmica de produção da cidade legal capaz de excluir uma significativa parcela dos habitantes do espaço efetivamente urbanizado, gerando situações de ilegalidade, ausência de infraestrutura e consequente degradação ambiental. No Brasil, a coexistência entre as condições de precariedade urbanística e os ecossistemas de grande fragilidade ambiental tem sido sistematicamente reconhecida, não apenas pela literatura, mas também, mais recentemente, pela grande impressa. 0 quadro de insuficiência de política habitacional de baixa renda, a enorme demanda por moradia de baixo custo, o crescente valor de uma boa localização no contexto intraurbano, graças ao crescimento do trabalho informal e à baixa qualidade do transporte público, além da insuficiência do controle urbanístico e poder de polícia do Estado alimentam o processo de ocupação urbana de áreas ambientalmente frágeis e com vantagens locacionais se comparadas à periferia. 0 fator ilegalidade agrava a questão ambiental, pois ele acaba por justificar condições insuficientes de infraestrutura urbana.

Entretanto, a coexistência entre favelas e áreas ambientalmente frágeis não significa que a manifestação da natureza no espaço urbano seja sempre um fator de desvalorização imobiliária. Determinados ecossistemas, escolhidos menos por seu valor ecológico e muito mais por sua localização no contexto intraurbano, são cuidadosamente produzidos para serem preservados (HARVEY, 1996). Muitos deles se tornam vantagens habilmente construídas pelo mercado imobiliário para atrair uma população com faixa de renda superior, disposta a morar em bairros afastados da zona central, com maior contato com a natureza. A mercantilização dos atributos ambientais do território tem se tornado um aspecto importante para o sucesso do fenômeno da dispersão urbana da classe média brasileira (COSTA, 2006).

Dentro de um contexto de contrastes nos modos de apropriação dos ecossistemas frágeis pelo processo de urbanização, este artigo adota como questão central o papel dos atributos ambientais do território nos fenômenos da valorização imobiliária e exclusão social urbana. Para tanto, analisa um território específico, a Região Metropolitana de Fortaleza. Questões similares já foram formuladas por outros autores em contextos internacionais semelhantes (EVANS, 2002; DAVIS, 2006). Este trabalho apresentará um caso brasileiro, chamando atenção para o papel das regulações de uso e ocupação do solo em perpetuar esse cenário de distribuição desigual dos recursos ambientais urbanos.

$\mathrm{O}$ artigo possui a seguinte estrutura. 0 primeiro capítulo aprofunda a discussão sobre associação do fenômeno da degradação ambiental e da exclusão urbana geradora de ilegalidade. 0 segundo capítulo apresenta as regulações brasileiras de uso e ocupação do solo, tanto com origem na política urbana como na política ambiental. Os dois capítulos seguintes apresentam a Região Metropolitana de Fortaleza, utilizada para ilustrar alguns dos argumentos previamente 
desenvolvidos. Estabelece-se neles um padrão diferenciado de ocupação dos espaços frágeis na escala metropolitana, trazendo ainda dois breves estudos de casos de assentamentos, nos quais as características ambientais foram determinantes em moldar seu padrão de ocupação: o Lagamar e o Eusébio.

0 contraste entre os casos apresentados contribui para a compreensão dos efeitos negativos da falta de integração entre as políticas ambientais e urbanas no contexto brasileiro. Por um lado, a política ambiental legitima um padrão de ocupação restritivo que inviabiliza o atendimento da enorme demanda habitacional de baixa renda; por outro lado as políticas urbanas têm aceitado - e algumas vezes incentivado - a regularização de assentamentos precários em áreas inadequadas do ponto de vista ambiental. Tendo como base os casos apresentados, ao fim do trabalho se discute a necessidade de o planejamento da expansão urbana seja ela horizontal ou através da verticalização - ter como foco o atendimento da demanda habitacional existente. Argumenta-se que tal medida é condição para que o Estado atue no sentido de conter o intenso processo de ocupação irregular de áreas ambientalmente vulneráveis.

\section{Associação entre exclusão urbana e degradação ambiental}

Nas cidades brasileiras, as características do quadro biofísico têm demonstrado capacidade de influenciar o padrão de diferenciação socioespacial urbano, ao permitir uma associação entre os espaços de exclusão urbana e aqueles de fragilidade ambiental. No Rio de Janeiro, a proximidade entre favelas e bairros nobres só foi permitida graças à existência de uma série de montanhas. Apesar da proximidade com a cidade valorizada, esses espaços de topografia acidentada foram desprezados pelo mercado imobiliário formal, em virtude do alto custo de urbanizá-los. Processo similar pode ser verificado em Fortaleza, onde as maiores concentrações de pobreza urbana próximas a bairros de alta renda estão em áreas de dunas, ou ao longo das margens alagáveis dos rios (FREITAS, 2004). Também em Brasília, as favelas localizadas nas proximidades no Plano Piloto ocupam espaços de solos hidromórficos (como a Vila Varjão), ou próximos a lixões (como a Vila Estrutural).
Obviamente, não se trata de coincidência o fato de que condições de precariedade social e urbana coexistem com ecossistemas de grande fragilidade ambiental. Davis (2006) elabora essa questão ao defender que, por traz desta coincidência atuam as leis de mercado, no caso o mercado de terras. Territórios com características desfavoráveis à urbanização são menos valorizados, e com frequência são deixados de lado pelos projetos de parcelamento da cidade formal destinados às classes de alta renda. Entretanto, a enorme demanda habitacional de baixa renda reprimida pela atuação elitista do mercado imobiliário formal, torna esses espaços desprezados uma oportunidade de moradia de baixo custo. Isso porque eles possuem uma característica essencial para a sobrevivência da população de baixa renda na cidade: a proximidade com os bairros de maior renda, que concentram oportunidade de empregos e geração de renda.

Vários autores utilizam o conceito vulnerabilidade socioambiental para referir-se ao fato de que grupos socialmente vulneráveis costumam localizar-se em espaços com características ambientais impróprias à ocupação urbana, o que acaba potencializando sua condição de vulnerabilidade, numa espécie de ciclo vicioso (i.e. ALVES, 2006). Em outras palavras: "ameaças naturais e induzidas atingem particularmente populações em situação de precariedade social, que contam com recursos limitados para fazer frente a esses eventos" (CIDADE, 2013). Cidade apresenta uma revisão dessa literatura, expondo uma evolução dos conceitos de risco, ameaça e vulnerabilidade. A autora identifica uma lenta aproximação entre questões tradicionalmente abordadas pelas ciências naturais - como as características biofísicas do território - e aquelas das ciências humanas, como as desigualdades entre grupos sociais.

Nesse movimento, no sentido da interdisciplinaridade, um aspecto relevante para o presente trabalho é o reconhecimento de que os atuais desastres ambientais urbanos, não constituem fenômenos estritamente naturais, mas são potencializados pela ação do homem, ou seja, pelo modelo de urbanização (SANTOS, 2007). Enchentes e deslizamentos de terras em áreas urbanas - que costumam ser descritos pela mídia como eventos naturais - são induzidos por um processo de urbanização ilegal, e desprovido de serviços básicos de infraestrutura, como redes de drenagem urbana e estabilização das encostas. 
Um dos primeiros a abordar essa questão no contexto brasileiro foi Torres (1997). 0 autor apresenta o conceito de desigualdade ambiental para problematizar a distribuição desigual de serviços urbanos básicos, destacando, em particular, a dimensão espacial do fenômeno. Ele inicia sua tese analisando a ocorrência de enchentes em São Paulo, mais frequente em bairros de baixa renda não atendidos pela rede de drenagem urbana. Ele questiona as decisões de alocação espacial ampliação da capacidade das redes de drenagem, ao revelar que a política pública de saneamento não prioriza os espaços com riscos de enchentes de maiores proporções, e em contraste, reinveste em áreas nobres.

A questão apresentada no Brasil inicialmente por Torres nos instiga a identificar os fatores que contribuem para a perpetuação de um modelo de urbanização gerador de tamanhas disfunções. Trata-se de uma questão complexa, que não pretendemos encerrar neste texto: são vários os fatores que contribuem para a inércia no sentido de reverter um processo de produção da cidade excludente, capaz de ampliar as desigualdades socioambientais urbanas no Brasil. Entretanto, esse texto enfatiza um aspecto que entendemos como crucial para a explicação desse fenômeno: a condição de ilegalidade dos bairros de baixa renda, que acaba por legitimar a manutenção de um padrão de urbanização incompleto e insuficiente. A próxima secção aborda a legislação brasileira de uso e ocupação do solo urbano, reconhecendo que alguns de seus dispositivos alimentam o ciclo vicioso da ilegalidade e degradação, em vez de combatê-lo preventivamente.

\section{Contradições entre as regras urbanas e ambientais brasileiras}

Regular o uso do solo em um cenário de rápida urbanização e ausência de serviços urbanos básicos constitui um desafio com consequências de proporções globais. Faz-se necessário reconhecer que a questão ambiental das cidades de terceiro mundo vincula-se à incapacidade das políticas públicas de universalizar o acesso ao mercado formal de habitação. Nesse sentido, deveria caber também às políticas de proteção do meio ambiente atuar preventivamente, contendo processos geradores de ocupação ilegal em áreas sensíveis. Assim como afirma Martins (2006, p. 138):
0 quadro de persistente permanência e ampliação da irregularidade dos assentamentos urbanos particularmente em áreas ambientalmente sensíveis levou à clara identificação de que a questão ambiental urbana - o avanço sobre áreas ambientalmente sensíveis e protegidas - é intrinsecamente associada à questão da moradia, à falta de oportunidades alternativas.

Do ponto de vista ambiental, essa é presentemente a grande pauta urbana. Pensar o tema ambiental nas grandes cidades brasileiras implica em discutir a questão do modelo de desenvolvimento urbano. É fundamental assumir que, sem forte investimento e prioridade ao desenvolvimento social, será impossível conseguir condições ambientais minimamente razoáveis, ainda que todas as indústrias sejam sujeitas a um forte e eficiente controle ambiental [...].

Ainda há, entretanto, um longo caminho para que a pauta ambiental urbana brasileira enfrente a questão da exclusão social e ilegalidade dos assentamentos de baixa renda. Ironicamente, a questão da proteção ambiental costuma ser colocada em oposição à inclusão urbana, e a recíproca também é verdadeira. Essa oposição não é exclusividade do Brasil e está presente também no contexto internacional, tendo sido reconhecida pela agenda 21 da ONU. Evans (2002) reconhece esse dilema e apresenta o conceito de livability para se referir a uma qualidade no processo de urbanização que considere ambas as dimensões mencionadas. A seguinte passagem de Evans (2002, p. 1-2) descreve essa contradição:

The coin of livability has two faces. Livelihood is one of them. Ecological sustainability is the other. Livelihood means jobs close enough for decent housing with wages commensurate with rents and access to the services that makes for a healthful habitat. Livelihood must also be sustainable. If the quest for jobs and housing is solved in ways that progressively and irreparably degrade the environment of the city, then the livelihood problem is not really being solved. Ecological degradation buys livelihood at expense of quality of life, with citizens forced to trade green spaces and breathable air for wages. To be livable, a city must put both sides of the coin together, providing livelihoods for its citizens, ordinary as well as affluent, in the ways that preserves the quality of the environment. 
No contexto brasileiro, diversas são as ocasiões nas quais as políticas que visam à proteção ambiental impedem um padrão de ocupação urbana acessível aos grupos de baixa renda, gerando maior desigualdade social. Por outro lado, o combate à exclusão urbana de grupos marginalizados por meio de programas de regularização de favela em áreas frágeis não tem contribuído para elevar a qualidade ambiental urbana. Essa contradição foi identificada por Fernandes (2006). 0 autor identifica um conflito entre o direito à cidade e a proteção ambiental no contexto das políticas brasileiras e argumenta ser esta uma falsa questão. Para ele, "os dois são valores e direitos sociais constitucionalmente protegidos, tendo a mesma raiz conceitual, qual seja, o principio da função socioambiental da propriedade" (FERNANDES, 2006, p. 1). De fato, tanto a função social da propriedade como sua função ambiental são conceitos capazes de impor limites ao interesse privativo do proprietário em prol dos interesses da coletividade, seja para as atuais ou as futuras gerações.

Nos últimos anos, o Brasil tem produzido uma vasta literatura em torno dessa aparente contradição (MARTINS, 2006; ANCONA, 2007; BEZERRA; CHAER, 2012). Essa literatura tem se concentrado no dilema mais visível nos fóruns de discussão a respeito da gestão ambiental urbana: a questão da regularização fundiária de assentamentos informais de baixa renda nas Áreas de Preservação Permanente (APP). Tal dilema impõe a escolha entre (1) recuperar ecossistemas urbanos legalmente protegidos, expulsando a população de baixa renda que ocupou o lugar, ou (2) aceitar a irreversibilidade da depredação do meio natural e garantir o direito à moradia da população. Tal situação coloca a questão ambiental e a questão social de lado opostos (FREITAS, 2009).

No entanto os mecanismos de planejamento capazes de evitar esse dilema socioambiental urbano são raramente explorados, apesar de serem reconhecidos por uma grande parte dos urbanistas. Refiro-me ao combate ao modelo de planejamento socialmente excludente e ambientalmente predatório ainda vigente na maior parte dos municípios brasileiros. Um modelo que permite processos especulativos com a terra urbana, impossibilitando à grande parte de seus habitantes o acesso à terra urbanizada.

Embora o Estatuto da Cidade (BRASIL, 2001), lei federal que estabelece as diretrizes da política urbana brasileira, reconheça a importância de políticas preventivas, ele não enfatiza os potenciais impactos ambientais do modelo excludente de produção da cidade. Isso acaba por contribuir para o atual cenário onde os instrumentos de regularização fundiária são muito mais adotados pelas políticas urbanas municipais do que os instrumentos de combate aos vazios urbanos dotados de infraestrutura (SANTOS Jr.; MONTANDON, 2011). Há muito mais avanços legais e institucionais na direção da regularização fundiária e da aceitação da precarização do padrão de urbanização do que na viabilização de modelos de ocupação urbana includentes, que garantam acesso à cidade formal, e aos espaços efetivamente urbanizados, para todas as classes sociais.

Desde a década de 1990, a política urbana federal caminha na direção de rebaixamento dos padrões urbanísticos dos loteamentos em áreas declaradas de interesse social — vide Lei n. 9.785 (BRASIL, 1999) — e recentemente estende tal exceção para a permissão da regularização de interesse social em APP, por meio da Lei n. 11.977 (BRASIL, 2009). Esta estabelece a possibilidade de supressão de APP em meio urbano para fins de urbanização de assentamentos de interesse social. Entretanto, tais mecanismo legais não reconhecem que as exceções estabelecidas impõem perda da qualidade ambiental urbana que deve ser compensada. Dessa forma, a legislação urbana federal aponta para uma situação já alertada por Evans (2002), que afirma não ser desejável o desenvolvimento urbano às custas da qualidade ambiental.

Entretanto, se, por um lado, os dispositivos da política urbana são falhos em assegurar a qualidade ambiental urbana e caminham no sentido de legalizar assentamentos com parâmetros de ocupação do solo ainda precários, por outro lado, ainda há um longo caminho a percorrer no sentido de incluir questões distributivas na agenda ambiental brasileira. Pode-se até mesmo afirmar que as regras de uso e ocupação do solo advindas das regulações ambientais têm caminhado na direção oposta, sugerindo parâmetros de ocupação do solo cada vez mais restritivos. Esse é o caso, por exemplo, da aplicação de APPs nas margens de rios urbanos. Ancona (2007) destaca que, desde a promulgação do Código Florestal, em 1965, essas faixas foram se ampliando, sem que houvesse um embasamento técnico para isso. 0 aumento das APPs acaba impondo um padrão de urbanização mais caro: diante da ausência do Estado, os produtores imobiliários transferem para o preço do lote produzido o custo da terra não comercializável da gleba. 
Outros exemplos de regulações ambientais que não atentam para a necessidade da inclusão socioespacial, podem ser encontrados nas regulações das áreas especialmente protegidas localizadas em meio urbano. No Brasil, os zoneamentos das Áreas de Proteção Ambientais (APAs) costumam adotar baixas densidades como a principal medida de proteção do meio ambiente, sem levar em consideração a existência de altos custos de instalação das redes de infraestrutura urbana em loteamentos pouco densos. Este é o caso da APA do Rio São Bartolomeu no Distrito Federal apresentada por Freitas (2009). Caso semelhante é o das Áreas de Proteção de Mananciais do estado de São Paulo apresentado por Martins (2006). A autora destaca que a proibição da urbanização de grande parte do território das bacias de mananciais na Região Metropolitana de São Paulo acabou induzindo uma desvalorização imobiliária, e a ocorrência de parcelamentos que, por serem ilegais, eram proibidos de receber as redes de infraestrutura. Sem tais serviços, esses assentamentos produziram, sobre o corpo d'água, impactos ambientais bastante superiores aos que ocorreriam se tivesse ocorrido um padrão de urbanização legal. Vale ressaltar, ainda, que o custo da urbanização de assentamentos localizados em ecossistemas frágeis tem-se mostrado bastante oneroso (ALVIM, 2011). Estabelece-se, assim, a ocorrência de um efeito reverso das restrições ambientais: ao impedir ou restringir a urbanização de grande parte das áreas ambientalmente protegidas, a legislação ambiental acaba por potencializar a degradação de ecossistemas importantes.

Outra questão relacionada à inadequação da legislação ambiental brasileira em meio urbano é uma percepção diferenciada a respeito da fragilidade do território, a depender de seu grau de valorização imobiliária. Trata-se de um processo de proteção ambiental seletiva, na medida em que os critérios técnicos relacionados ao quadro físico-natural nem sempre são os fatores determinantes para estabelecer restrições de uso e ocupação do solo. Ecossistemas inseridos em áreas nobres tendem a ser compreendidos como espaços de maior valor ecológico para justificar a adoção de parâmetros urbanísticos excludentes. 0 zoneamento da APA do Rio São Bartolomeu apresenta tal situação: sistemas de terras com menor grau de fragilidade, e boa inserção urbana, apresentam parâmetros legais de ocupação - tamanhos mínimos de lotes e densidades - mais restritivos do que os sistemas de terras mais frágeis localizados em espaços periféricos. Trata-se de um processo perverso cujos defensores se apropriam da proteção ambiental a determinados ecossistemas para favorecer a reserva de terras para o mercado imobiliário de alta renda. Tal processo tem como resultado direto a concentração de degradação ambiental e vulnerabilidades sociais nas áreas periféricas (FREITAS, 2009).

Percebem-se, portanto, duas visões setorizadas e extremas que não demonstram compreensão da complexidade do processo de produção da cidade: aquela dos defensores do rebaixamento dos parâmetros urbanísticos em nome do acesso à cidade para a população de baixa renda, e aquela dos defensores de parâmetros urbanísticos restritivos em nome da preservação ambiental a qualquer custo. A esses dois grupos de atores, interessa a adoção de mecanismos de combate ao modelo excludente de produção da cidade, que já estão timidamente inseridos no arcabouço legal brasileiros - como as Zonas Especiais de Interesse Social (ZEIS) de Vazio e o IPTU Progressivo -, mas encontram enorme dificuldade política para serem viabilizados. Ao primeiro grupo, interessa combater a especulação imobiliária no sentido de aumentar a oferta de terra urbanizada e portanto as possibilidade da população de baixa renda acessar a cidade. Ao segundo grupo, interessa atender ao direito à moradia em áreas propícias ao desenvolvimento urbano, reduzindo a pressão por ocupações precárias em áreas ambientalmente frágeis.

Infelizmente, essa bandeira ainda não foi internalizada pelos gestores ligados à proteção ambiental no Brasil. 0 processo de revisão do Código Florestal brasileiro foi uma oportunidade perdida nesse sentido. A lei aprovada em 2012 não aborda a especificidade do urbano, reproduzindo um desgastado ponto de vista de natureza em oposição à cidade. A mesma não articula com os planos diretores urbanos e nem com as ZEIS (BEZERRA; CHAER, 2012). Em uma versão preliminar que tentou abordar a questão urbana, a lei chegou a adotar a exigência de $20 \mathrm{~m}^{2}$ de área verde por habitante, parâmetro impossível de ser atingido em assentamentos de baixa renda com densidades médias e altas. Assim, questões de natureza estrutural, como o desequilíbrio entre os direitos coletivos - à moradia e à qualidade ambiental urbana - e 0 direito de propriedade, permanecem intocadas.

No sentido de aprofundar algumas das reflexões abordadas até aqui, o próximo capítulo apresenta 
processos de apropriação do meio ambiente na Região Metropolitana de Fortaleza.

\section{A Região Metropolitana de Fortaleza}

A Região Metropolitana de Fortaleza (RMF) é composta por 15 municípios, e ocupa uma área total de cerca de 580 mil hectares. Possui uma população de 3,6 milhões habitantes em cerca de 1 milhão de domicílios, distribuídos de forma desigual no território, com forte concentração no município central de Fortaleza (68\% da população total), seguido de Caucaia $(8,9 \%)$ e Maracanaú (5,7\%) (IBGE, 2010). De acordo com a classificação do IBGE, a área urbana da RMF corresponde a cerca de 95 mil hectares, ou 16,47\% da área total da RMF.

Em termos de regulação urbana, a mancha urbana está prevista para se expandir na direção leste: cerca de 70 mil hectares estão classificados nos planos diretores municipais como área de expansão urbana. Note-se que a área de expansão urbana localiza-se, em sua maior parte, nos municípios a leste de Fortaleza (ver Figura 1). Tais municípios são mais valorizados graças à forte dinâmica do turismo no litoral leste, e à expansão da dinâmica imobiliária formal de alta renda de Fortaleza que atua preferencialmente no setor leste da cidade. Contraditoriamente, a concentração populacional é maior nos municípios a oeste, região que historicamente tem recebido os conjuntos habitacionais e os distritos industriais, com terra mais barata e

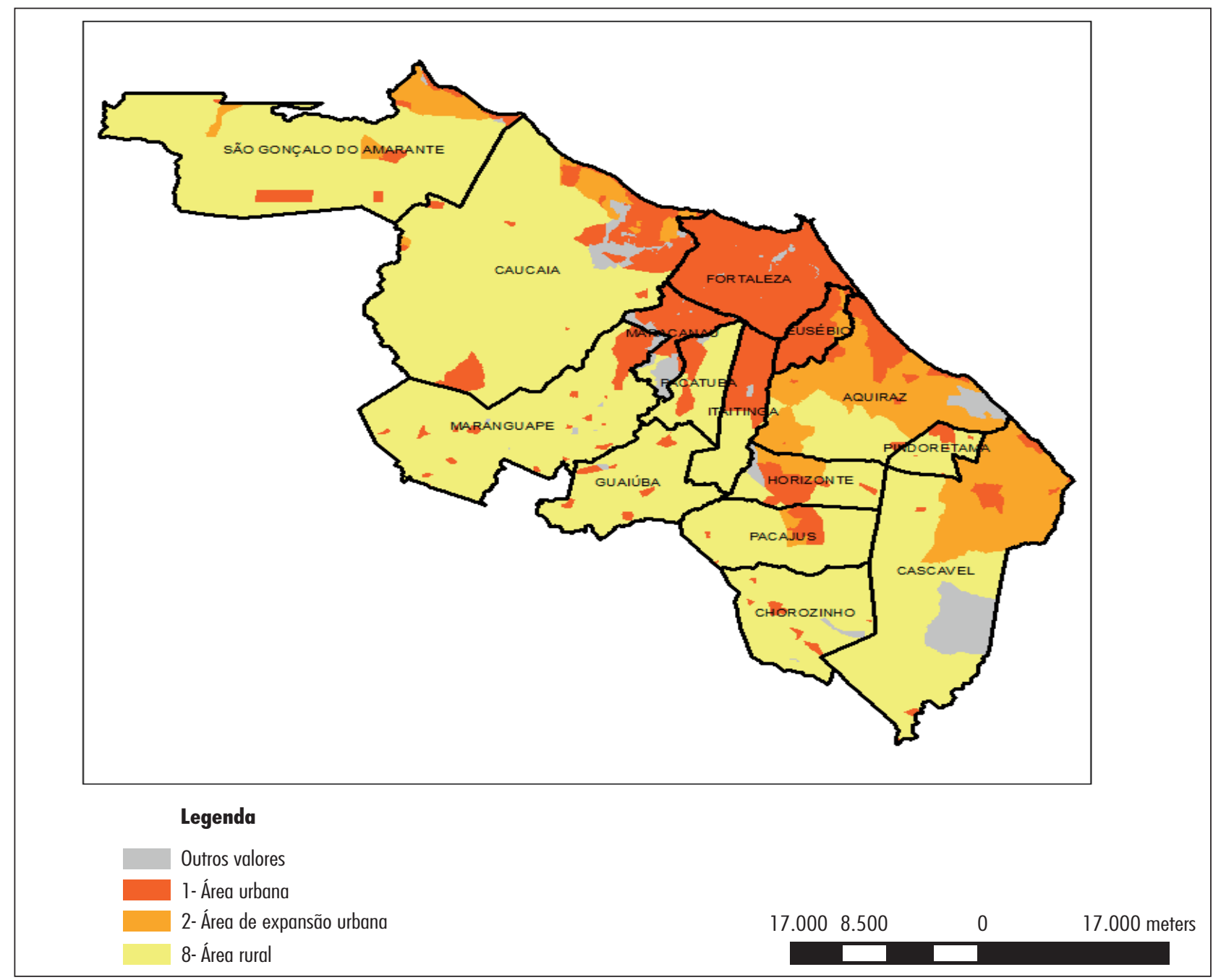

Figura 1 - Região Metropolitana de Fortaleza, área urbana e área de expansão urbana Fonte: Elaborado pela autora a partir de IBGE, 2010. 
serviços urbanos de pior qualidade. Percebe-se, assim, uma dinâmica urbana excludente, com grande oferta de espaço urbanizável destinado a setores de renda mais alta, contrastando com a grande demanda habitacional concentrada em estratos de renda inferior.

De acordo com dados da Fundação João Pinheiro (2008), o deficit habitacional da RMF é de 101.266 unidades habitacionais, das quais 94,6\% correspondem a famílias de 0 a 3 salários mínimos. Essa demanda por habitação não é atendida pelo mercado imobiliário formal. Embora tenha havido um movimento recente no sentido de deselitização da produção imobiliária formal, a demanda de interesse social continua não atendida pelo mercado formal (FREITAS; PEQUENO, 2011). Assim, as famílias de baixa renda continuam recorrendo ao mercado imobiliário informal, o que pode ser constatado pelo contínuo movimento de expansão de assentamentos ilegais de baixa renda. A Figura 2 ilustra a contradição entre a demanda habitacional e a oferta no mercado imobiliário formal por faixa de renda na cidade de Fortaleza.

As áreas de maior sensibilidade ambiental em Fortaleza correspondem às margens inundáveis dos rios urbanos - que desembocam no mar formando ecossistemas de mangues - e as faixas de dunas que se configuram de forma paralela ao litoral norte e litoral leste. Fortaleza possui duas grandes bacias hidrográficas: a Bacia do Rio Maranguapinho, a oeste, que se encontra bastante adensada, embora com uma cobertura de serviços de saneamento ainda insuficiente; e a Bacia do Cocó, a leste, que, em virtude da menor densidade média de ocupação e da existência do Parque do Cocó apresenta melhores indicadores de qualidade de água.

Grande parte dos espaços caracterizados como inadequados para a urbanização, do ponto de vista do quadro natural, encontram-se ocupados por assentamentos ilegais de baixa renda. Para embasar essa afirmação, utilizamos duas fontes de dados recentemente divulgadas: o Diagnóstico Geoambiental de Fortaleza (SOUZA, 2009), que classifica os sistemas ambientais indicando aqueles mais frágeis ou mais estáveis para urbanização; e o Plano Local de Habitação de Interesse Social (PLHIS) em sua versão preliminar, disponibilizada pela prefeitura municipal de Fortaleza em março de 2011. Sobrepôs-se o Diagnóstico Geoambiental ao mapeamento dos assentamentos precários do PLHIS, para verificar em que medida as áreas de ocupação informal se localizavam em sistemas ambientais frágeis. Constatamos que, dos 707 assentamentos mapeados pelo PLHIS até início de 2011, 194 localizavam-se pelo menos parcialmente em áreas frágeis. Acrescentando os assentamentos localizados em áreas medianamente frágeis são 234. Essas 234 áreas representam $66,6 \%$ do território dos assentamentos informais da cidade mapeados pela pesquisa (ver Figura 3).
Percentual do deficit habitacional da Regí̃o Metropolitana de Fortaleza

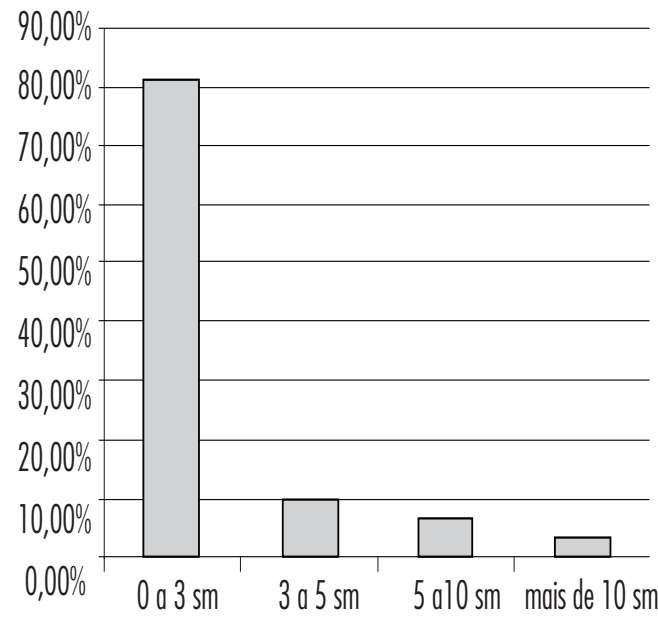

Ofertas de novas unidades habitacionais em Fortaleza, em fevereiro de 2010

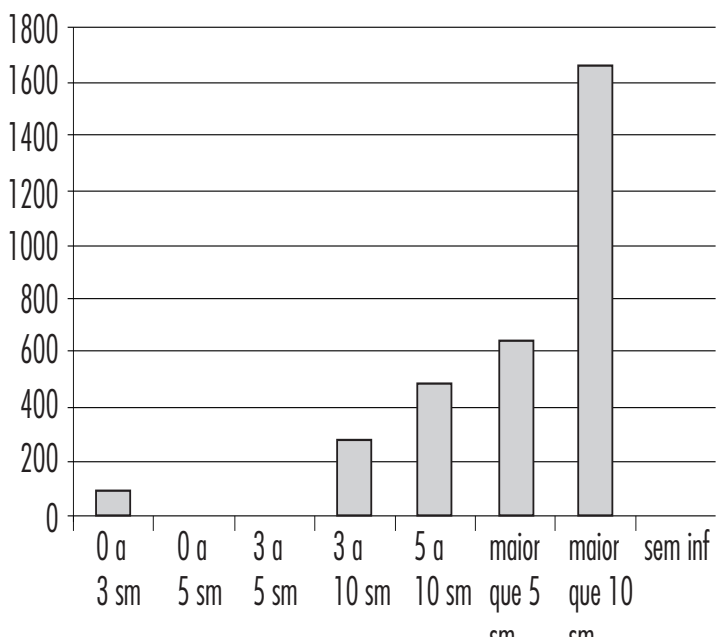

$\mathrm{sm} \quad \mathrm{sm}$

Figura 2 - Demanda por habitação por classe de renda e a oferta no mercado imobiliário formal

Fonte: Elaborado pela autora a partir de dados da Fundação João Pinheiro e do Índice de Velocidade de Vendas do Sinduscon-CE. 


\section{Ocupações irregulares de baixa renda em áreas frágeis: o Lagamar}

Um desses casos de assentamentos informais localizados em áreas impróprias para urbanização é o Lagamar. 0 Lagamar é um dos maiores e mais antigos assentamentos informais de Fortaleza. Localizase nas duas margens do Riacho Tauape, um afluente do Rio Cocó que está canalizado desde o início da década de 80. Está localizado na zona leste de Fortaleza, que abriga os bairros mais valorizados, como Aldeota, Meireles e Papicú. Dispõe, portanto, de uma localização privilegiada, a $5 \mathrm{~km}$ do centro, a $6 \mathrm{~km}$ da avenida Beira-mar, a $4 \mathrm{~km}$ do Shopping Iguatemi, e a $6 \mathrm{~km}$ do aeroporto. Apresenta nível satisfatório de atendimento a equipamentos sociais como escolas, postos de saúde e centros de assistência social.

No que se refere à dinâmica populacional do Lagamar, sabe-se da existência de ocupações desde a década de 1950, formadas originalmente por famílias vindas do interior do estado, em épocas de seca. Entretanto, o aumento do número de famílias se deu a partir da década de 80 , e se relaciona diretamente com o período de recessão econômica e falta de alternativa de habitação de interesse social em espaços que guardam boa relação de proximidade com a porção da cidade concentradora de empregos e oportunidades de renda. Em 2010, sua população está estimada em 17.760 habitantes (IBGE, 2010) em uma área de 47 hectares. 0 fim do período de recessão econômica no início da década de 2000 não foi

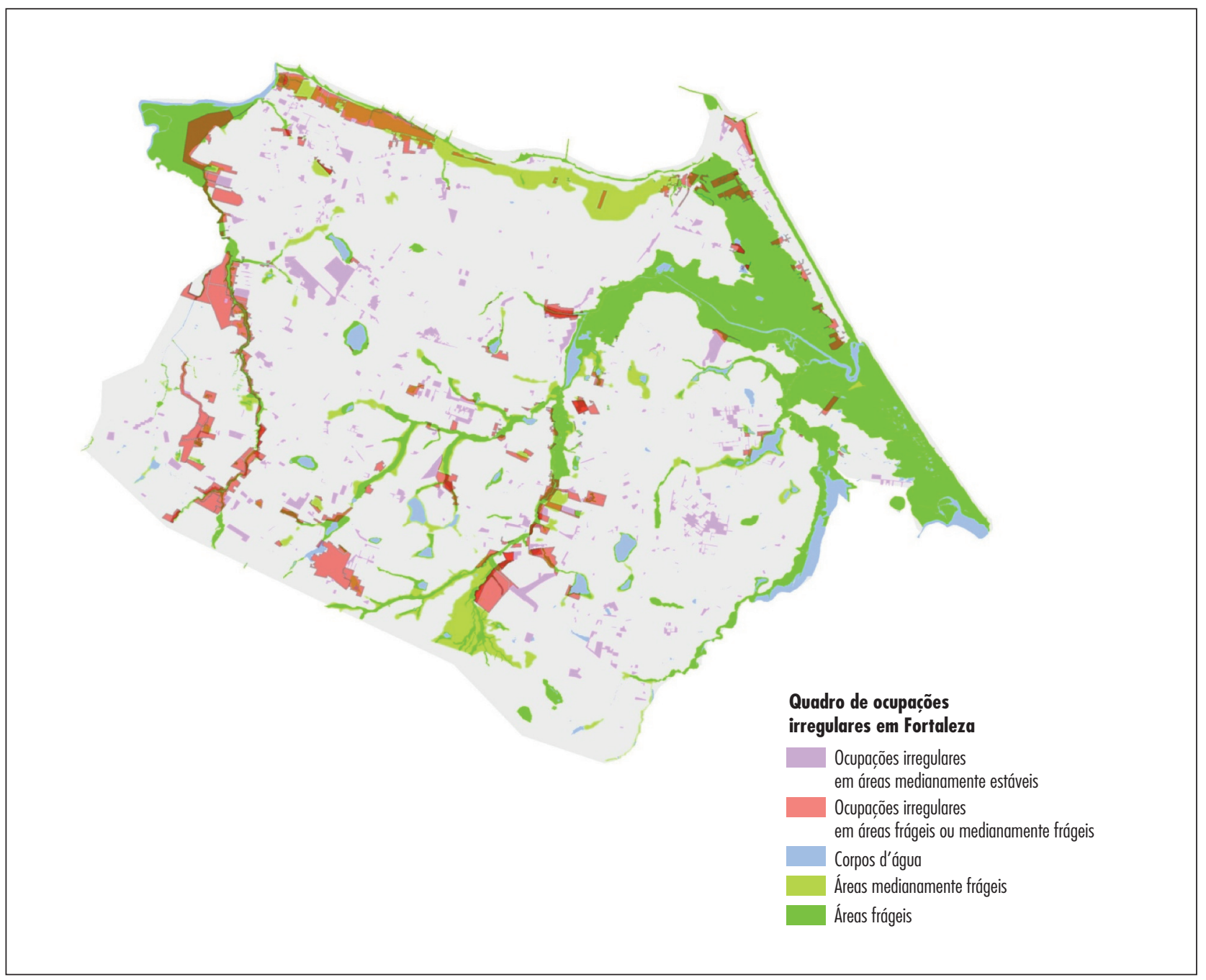

Figura 3 - Sobreposição entre áreas de sensibilidade ambiental e os assentamentos precários Fonte: PINHO; FREITS, 2012. 
suficiente para conter o avanço das ocupações ilegais na região do Lagamar: uma análise das fotos aéreas e das cartografias disponíveis nos permitiu identificar a ocupação de dois grandes terrenos vazios existentes em 2003. Essas áreas de ocupação recentes apresentam nível de precariedade habitacional superior à media do assentamento, exibindo, dentre outros problemas, alto percentual de moradias sem banheiro.

O descontrole no processo de ocupação do Lagamar agrava as inúmeras carências existentes. Dentre as carências, destacam-se a insuficiência de espaços de lazer e as precárias condições de habitabilidade, em particular o adensamento excessivo e uma série de vielas de pedestres de grande comprimento, que dificultam a extensão das redes de infraestrutura sanitária para todas as casas. Em termos de configuração espacial, os problemas se acentuam à medida que nos aproximamos do fundo do vale do Riacho Tauape, que corresponde à área sujeita a enchentes periódicas e reincidentes. A excessiva impermeabilização da bacia do riacho, aliada à insuficiência das redes de drenagem e assoreamento do leito do canal, fez as partes baixas da bacia se tornarem espaços desvalorizados e, portanto, as únicas áreas acessíveis à população de baixa renda. A Figura 4 ilustra que, na medida em que as casas aproximam-se do canal, seu tamanho se reduz, indicando que o fenômeno da desvalorização ambiental também pode ser percebido na escala do assentamento, e não apenas na escala da cidade como um todo.

Uma série de restrições advindas da agenda urbana e ambiental incide sobre o território do Lagamar. Do ponto de vista urbanístico, o Lagamar foi classificado como ZEIS em 2010, embora até hoje permaneça em um cenário de indefinição das regras de ocupação vigentes. Trata-se de um processo politicamente difícil, pois alguns meses após a delimitação do Lagamar como ZEIS, Fortaleza foi escolhida como cidade-sede da Copa do Mundo, e a prefeitura e o Estado apresentaram dois projetos que atingem diretamente a comunidade: (1) o projeto do viaduto da Av. Raul Barbosa na porção sudeste do assentamento, que prevê a desocupação das casas mais antigas da comunidade; e (2) o projeto do VLT, que prevê a

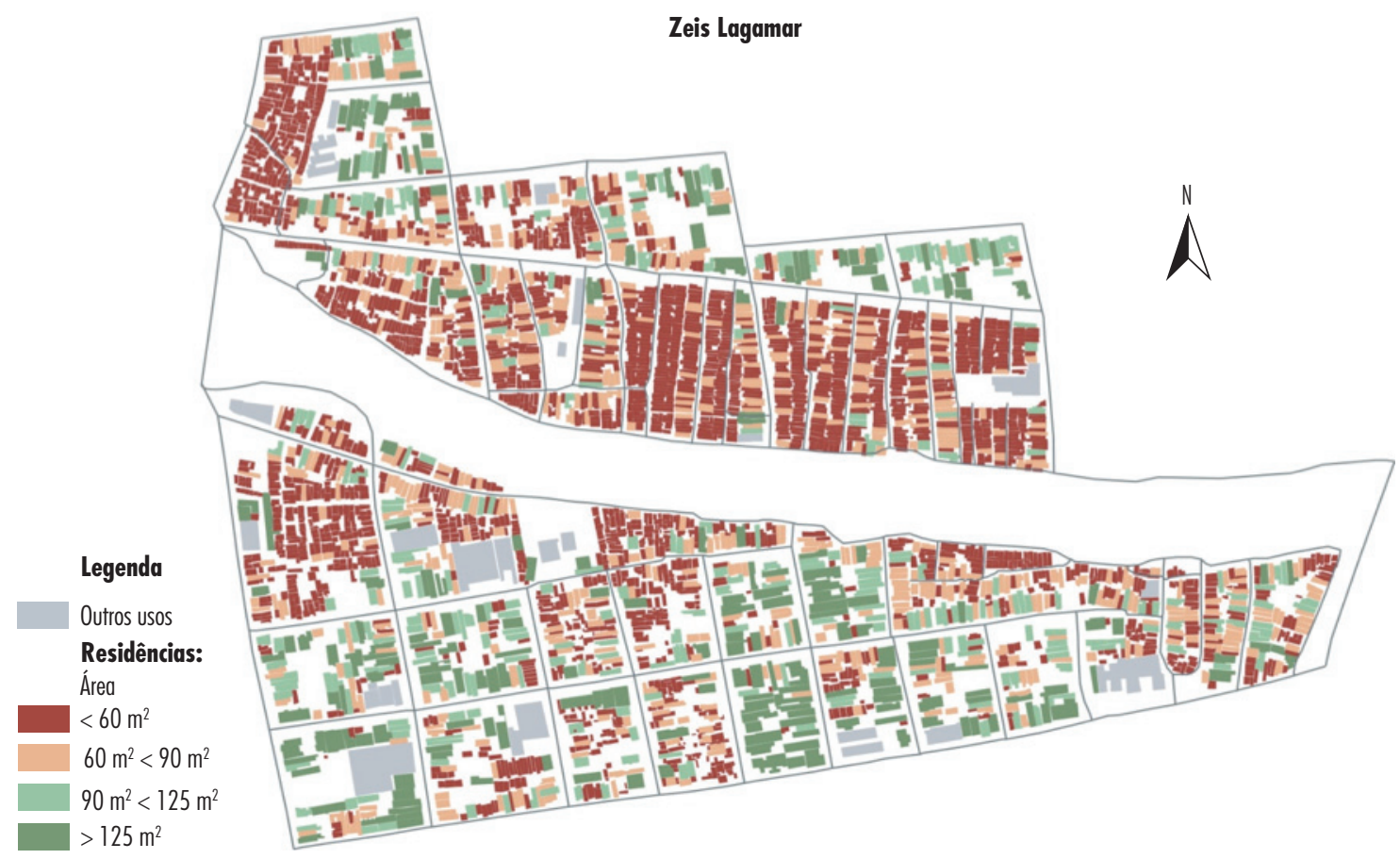

Figura 4 - Tamanhos de lotes no Lagamar

Fonte: Elaborado pela autora a partir de foto aérea fornecida pela Prefeitura Municipal de Fortaleza. 
construção da estação São João do Tauape na porção norte do assentamento. Assim, se por um lado a ZEIS garante conceitualmente a permanência das famílias e o direito à regularização fundiária, por outro lado os projetos da Copa propõem a remoção de cerca de 500 famílias e uma escola. Além disso, os projetos não preveem a utilização de áreas delimitadas como ZEIS de vazio para reassentamento da população removida, propondo o reassentamento em um bairro periférico, diagnosticado pelo plano diretor como uma área carente de infraestrutura e serviços.

Com a intenção de amenizar essa tensão entre objetivos claramente contraditórios, no início de 2012 a prefeitura apresentou uma proposta de regulamentação urbanística da ZEIS ao seu Conselho Gestor. Esse projeto não parte de uma leitura dos padrões urbanísticos existentes na comunidade, e propõe parâmetros que implicam a legalização de situações de precariedade, como a adoção de lotes mínimos de $25 \mathrm{~m}^{2}$, taxas de ocupação de $80 \%$ no interior do lote. A adoção de tais parâmetros implicaria a legalização da precarização do assentamento, tendo em vista que ele permitiria a subdivisão de um lote de $50 \mathrm{~m}^{2}$ (muito comum) em dois. Por outro lado, a taxa de ocupação de $80 \%$ requereria a reforma de uma grande número de casas, pois poucos domicílios possuem $20 \%$ do lote de área permeável. A proposta de regulamentação prevê ainda a liberação de um percentual de áreas do assentamento destinadas a praças, mas não localiza quais domicílios seriam removidos, além de não fazer menção a existência de uma APP dentro dos limites da ZEIS. Em suma, os impactos da adoção dessas regras não foram mensurados.

Essa proposta de regulamentação não foi aceita pelos membros do conselho gestor, que ainda lutam por um estudo aprofundado de reconhecimento do padrão de ocupação do território, de forma a subsidiar projetos de urbanização que visem à qualificação urbanística e ambiental do assentamento. Até o presente momento, a prefeitura não apresentou iniciativas nesse sentido. Enquanto um estudo urbanístico do assentamento não se viabiliza, o poder público municipal continua atuando no assentamento de modo setorizado, e pontual, focando apenas nas áreas demandadas para os projetos da Copa do Mundo, sem solucionar situações de risco e precariedade do assentamento.

Do ponto de vista da legislação ambiental, cabe destacar que a área dentro da faixa de $50 \mathrm{~m}$ de distância do canal corresponde a uma APP. A partir de trabalho de campo, podemos constatar que a área que sofre inundações periódicas corresponde à cota 04, que, em algumas ocasiões, é maior que que a faixa delimitada legalmente como APP, e em outras, é menor. Nesse sentido, percebe-se que a restrição legal de urbanização de uma faixa de largura fixa paralela à margem do rio não soluciona as questões de risco socioambiental e preservação da margem de inundação sazonal do corpo hídrico, conforme destacado por Mota (2003). Assim, no caso das APPs do Lagamar, há, em algumas situações, excesso de restrição e, em outras, certa permissividade.

Junto com a área correspondente à APP existem ainda outras áreas legalmente proibidas de serem urbanizadas como as praças e áreas verdes de loteamentos aprovados, e leitos do sistema viário desses mesmos loteamentos. Outro tipo de ilegalidade urbanística recorrente no Lagamar é o desmembramento não autorizado dos lotes de um loteamento aprovado na década de 50. Esses lotes possuíam originalmente tamanhos médios de $400 \mathrm{~m}^{2}$, e foram subdivididos produzindo inúmeros tipos de adaptações no tecido urbano original. Tal processo ilustra os efeitos insustentáveis de um modelo de produção de cidade que permite que a sobreoferta de loteamentos para classes mais altas coexista com a demanda reprimida de moradia social, já comentado anteriormente. Alguns desses parcelamentos não resistem às pressões e acabam sendo invadidos ou reparcelados pelos seus proprietários. Outros permanecem vazios por muitos anos, como é o caso dos parcelamentos aprovados no município do Eusébio.

\section{Processo de expansão urbana da cidade formal: Eusébio}

O Eusébio é um município relativamente pequeno, com 7.895 hectares e cerca de 46 mil habitantes (em 2010), localizado a leste de Fortaleza. Graças a sua proximidade com os bairros que concentram os investimentos imobiliários em Fortaleza, hoje o município constitui a fronteira de expansão do mercado imobiliário formal destinado à alta renda (ver Figura 5). Tal condição acentua-se particularmente após a conclusão de grandes investimentos estatais em acessibilidade, como a duplicação da CE-040, projeto iniciado ainda na década de 90 . Com a finalização desse projeto na década de 2000, o Eusébio entra definitivamente no 
mercado de loteamentos residenciais de alto padrão, sendo frequentemente descrito pelos anúncios publicitários como um bairro de Fortaleza.

Do ponto de vista do quadro natural, o território do Eusébio é rico em recursos hídricos, podendo ser percebido grande número de lagoas e importantes rios e riachos, dentre eles a Lagoa da Precabura, o Rio Pacoti e o Riacho Coaçú. Apresenta as unidades geoambientais da planície flúvio-marinha, na sua porção norte e nordeste, dos tabuleiros pré-litorâneos, predominante no território, das planícies fluviais e planícies flúvio-lacustres, configurando um mosaico de paisagens naturais, com diferentes níveis de estabilidade (EUSÉBIO, 2008). A mancha urbana principal coincide com os tabuleiros pré-litorâneos, que corresponde ao sistema de maior estabilidade e capacidade de suporte para o processo de urbanização.

0 modelo de ocupação desse território recorre à privatização dos recursos naturais, restringindo o acesso a eles, por meio do cerramento de pequenos condomínios ou de grandes loteamentos. $\mathrm{Na}$ verdade, a preservação desses espaços costuma variar de acordo com o perfil de renda a que o loteamento se destina, não sendo raros os casos de depósito de lixo em áreas verdes de loteamentos voltados a classes de renda média. Em contraste, aqueles destinados às classes de renda superior dispõem de um padrão de urbanização nas áreas livres capaz de aliar a atividade de preservação ambiental com a atividade de lazer e contemplação.

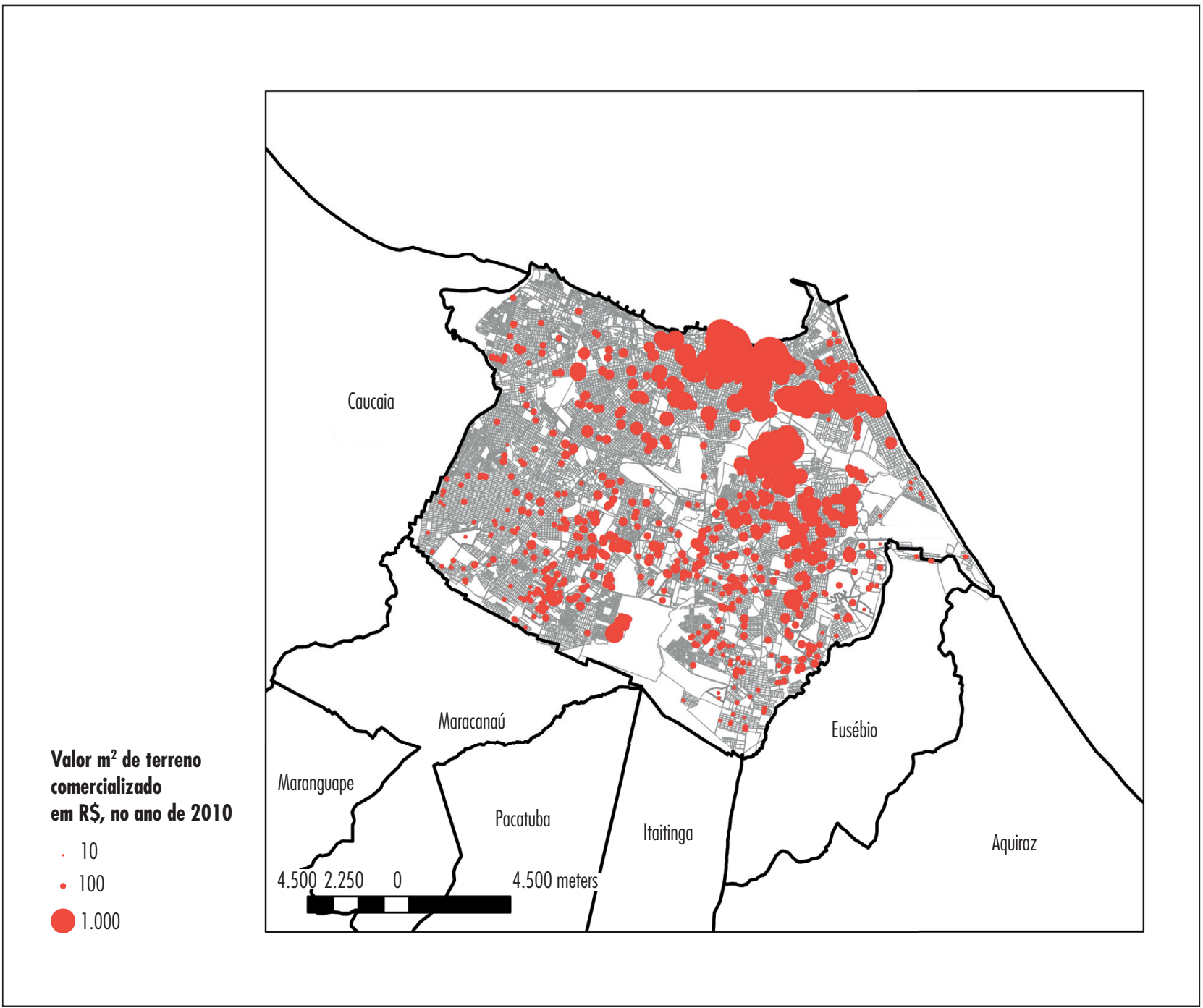

Figura 5 - Valorização Imobiliária em Fortaleza

Fonte: Elaborado pela autora a partir de PREFEITURA MUNICIPAL DE FORTALEZA, 2010. 
Nessas ocasiões, percebe-se nos anúncios publicitários a descrição do lugar como um território de características ambientais singulares e merecedores de preservação ambiental. Tal afirmação não se sustenta se considerarmos que se trata de uma região de tabuleiro pré-litorâneo, sistema ambiental similar a grande parte do território da capital, e bastante adequado ao processo de urbanização (SOUZA, 2009; EUSÉBIO, 2008). Trata-se, portanto, de uma estratégia de mercantilização dos atributos ambientais, que agregam valor aos preços dos lotes comercializados, similar ao processo já diagnosticado por Costa (2006) na periferia rica da Região Metropolitana de Belo Horizonte.

A Figura 6 ilustra um caso em que a privatização do recurso natural é feita de modo a valorizar o empreendimento, sendo agregado o valor paisagístico-natural ao preço do lote. No caso da zona em que esse empreendimento está localizado, o Plano Diretor Participativo do Eusébio (2008) estabelece padrões de baixa densidade para o município, com o lote mínimo de $150 \mathrm{~m}^{2}$. Esse parâmetro foi estabelecido por uma mudança recente, visto que o plano anterior (de 2001) indicava um lote ainda maior, de $300 \mathrm{~m}^{2}$. Grande parte dos condomínios da região atende ao lote mínimo de $300 \mathrm{~m}^{2}$, que só possibilita o acesso das classes de maior poder aquisitivo (PINHO; FREITAS, 2012). Além disso, é interessante perceber que a delimitação de parâmetros urbanísticos excludentes, como o tamanho do lote mínimo de grandes dimensões, atua no sentido de valorização imobiliária. Embora haja uma permissão para a urbanização com parâmetro menos elitista, essa permissão não foi efetivada, pois não interessa aos promotores imobiliários a popularização do padrão de urbanização.

0 zoneamento ambiental proposto pelo plano diretor aprovado em 2008 adota uma Zona Ambiental Paisagística correspondente a uma faixa marginal adicional paralela às APPs. Em tal zona é permitida apenas parcelamentos com lotes mínimos de $500 \mathrm{~m}$, o que, na prática, impede uma aproximação de assentamentos adensados com o corpo hídrico. Entretanto, é importante destacar que o controle do tamanho mínimo do lote como mecanismo e preservação ambiental não se sustenta. Diversos autores têm destacado as vantagens ecológicas da adoção de maiores densidades, no sentido de viabilizar a instalação de redes de infraestrutura sanitária e transportes urbanos, cuja ausência é a grande

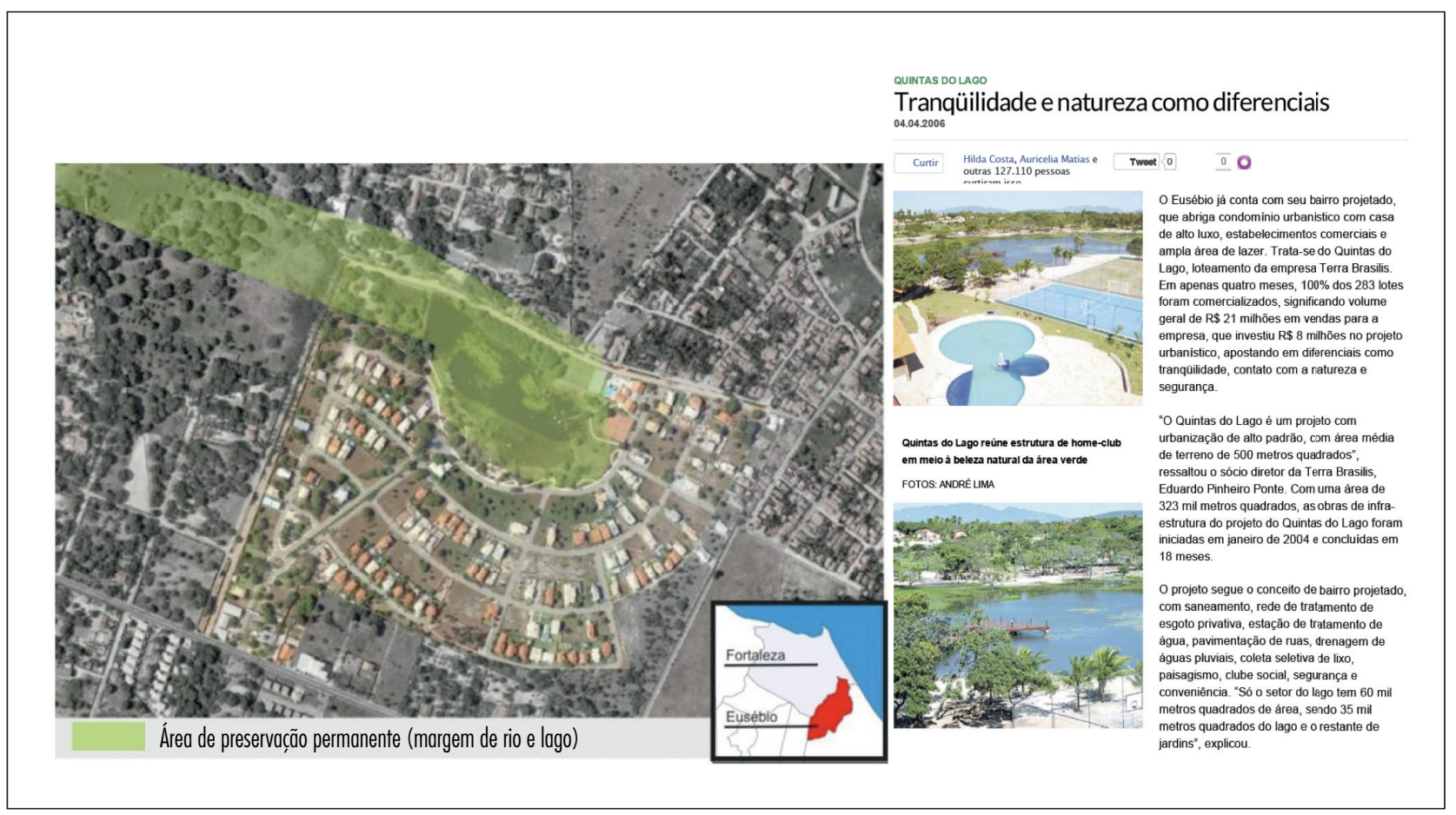

Figura 6 - Loteamento no município do Eusébio

Fonte: PINHO; FREITAS, 2012; JORNAL DIÁRIO DO NORDESTE, 2006. 
responsável pela degradação ambiental urbana (MOTA, 2003; MORETTI, 1997). Por outro lado, a restrição demasiada acaba por induzir a urbanização irregular como no caso da área de proteção de mananciais em São Paulo, previamente comentada.

Assim, embora o plano diretor aprovado demonstre certa preocupação com a inclusão urbana através da sugestão de instrumentos urbanísticos de combate à retenção especulativa de terra urbanizada como as ZEIS, tais mecanismos não se viabilizam politicamente. Em contraste, a adoção de parâmetros restritivos em nome de um suposto ganho ambiental parece ser mais viável politicamente.

Nunca é demais destacar que a relação entre o padrão de ocupação do solo e perfil de renda dos ocupantes é bastante direta: lotes maiores costumam ser mais caros e, portanto, destinados a faixas de renda superiores. 0 argumento fica mais claro quando comparamos o padrão de ocupação do solo dos loteamentos no Eusébio com o do Lagamar em Fortaleza. Enquanto o município de Fortaleza indica lotes mínimos de $125 \mathrm{~m}^{2}$ e $62,5 \mathrm{~m}^{2}$ para Habitação de Interesse Social, o lote médio encontrado na comunidade do Lagamar é de $56 \mathrm{~m}^{2}$. Por outro lado, o município do Eusébio indica o lote mínimo de $150 \mathrm{~m}^{2}$, e possui grande parte dos lotes acima de $300 \mathrm{~m}^{2}$. Percebe-se, assim, a distância entre os padrões legais dos dois municípios, e entre os padrões apresentados nos dois assentamentos. 0 contraste de indicadores urbanísticos entre os dois assentamentos se torna ainda mais claro se compararmos a densidade dos dois assentamentos: enquanto no Lagamar temos uma densidade de 375,76 hab/ha, o Eusébio apresenta uma densidade de 24,29 hab/ha.

No que se refere ao modelo de ocupação do território dos dois casos analisados, outro ponto a ser destacado relaciona-se à velocidade de ocupação dos lotes. Observa-se que, no caso do Eusébio, o ritmo de ocupação é lento, graças à baixa demanda habitacional do perfil de renda a que ele se destina. 0 reflexo disso é que grande parte do território municipal já é parcelado, entretanto muitos desses loteamentos não foram construídos e poucos se encontram totalmente ocupados. Enquanto isso, áreas ambientalmente frágeis são ocupadas de modo acelerado, visto que a demanda por moradia de baixo custo é muito alta, e esse produto não é ofertado em quantidade suficiente pelo mercado imobiliário.

\section{Considerações finais: o planejamento da expansão urbana}

A análise da Região Metropolitana de Fortaleza fornece subsídios para uma melhor compreensão do modo como as características biofísicas do território são capazes de direcionar o padrão de segregação socioespacial intraurbano, potencializando uma tendência de exclusão socioespacial característica de cidades de terceiro mundo. Fortaleza apresenta clara predominância de ocupações irregulares e precárias nas margens dos rios urbanos (Cocó e Maranguapinho) e nas faixas de dunas litorâneas (Pirambú e Castelo Encantado). Tais espaços, apesar de difícil ocupação apresentam grande proximidade com as zonas geradoras de empregos e rede de serviços sociais urbanos.

Ao analisar a aplicação da legislação urbanística/ ambiental na escala dos assentamentos, no caso do Lagamar e do Eusébio, percebemos que as normas caminham na direção da inclusão urbana embora não consigam ser efetivadas. A instalação da ZEIS no Lagamar e a redução do tamanho mínimo do lote no Eusébio, não foram suficientes para reconhecermos um avanço na direção da inclusão e redução da pressão sobre os ecossistemas frágeis. Há uma enorme dificuldade de viabilização política na produção de assentamentos financeiramente acessíveis em espaços propícios, no ponto de vista do quadro natural, ou mesmo na permanência da população de baixa renda em espaços disputados pelo mercado imobiliário, a despeito das fragilidades ambientais apresentadas.

Por outro lado, não podemos perder de vista que a preocupação ambiental pode gerar espaços possíveis de reversão de certas lógicas de produção do espaço da cidade. E exatamente por sua capacidade transformadora, os agentes ligados à agenda ambiental devem reconhecer seu papel em viabilizar politicamente a implantação de modelos de urbanização includentes, abandonando uma visão simplista da oposição entre natureza e cidade. Tal visão deve dar lugar à busca por mecanismos de planejar o território que privilegiem os interesses coletivos sobre os individuais, considerando concomitantemente os direitos ambientais e sociais.

Essa discussão traz à tona a necessidade de que o planejamento da expansão urbana inclua um efetivo controle do Estado sobre a atuação dos agentes do mercad, no sentido de conter os 
processos de aumento especulativo dos preços dos terrenos, e implantar políticas de combate a retenção do lote vazio. 0 foco na questão das áreas de expansão justifica-se no sentido de evitar a reprodução do fenômeno da exclusão social e da degradação ambiental já presente nas áreas centrais consolidadas. Nota-se a necessidade de propor um modelo de ocupação de forma integrada, visando a atender aos interesses ambientais por meio da inclusão da grande parcela da população sem acesso à moradia na cidade urbanizada, ou seja, na cidade formal dotada de serviços urbanos e qualidade urbano-ambiental mínima.

Essa questão tem começado a informar a política pública brasileira. Diante de um processo de urbanização insustentável que produziu diversos desastres ambientais urbanos de grandes proporções - como inundações e desmoronamentos em grande medida causados por um modelo de urbanização ilegal -, foi editada a medida provisória 547, de 2001. Nessa medida, posteriormente transformada na Lei n. 12.608/2012, pode-se perceber um avanço no sentido de tentar evitar o conflito ambiental urbano, ao sugerir instrumentos de prevenção do quadro de urbanização insustentável em que vivemos. Ela institui a realização de um cadastro nacional de municípios com áreas de risco e a obrigatoriedade de normas específicas para loteamentos aprovados em áreas de maior vulnerabilidade. Ela determina ainda que sejam feitos planos de expansão urbana toda vez que se quiser ampliar o perímetro urbano de uma cidade ao qual denomina projeto específico:

[...] 42-B: Os Municípios que pretendam ampliar o seu perímetro urbano após a data de publicação desta Lei deverão elaborar projeto específico que contenha, no mínimo: I - demarcação do novo perímetro urbano; II - delimitação dos trechos com restrições à urbanização e dos trechos sujeitos a controle especial em função de ameaça de desastres naturais; III - definição de diretrizes específicas e de áreas que serão utilizadas para infraestrutura, sistema viário, equipamentos e instalações públicas, urbanas e sociais; IV - definição de parâmetros de parcelamento, uso e ocupação do solo, de modo a promover a diversidade de usos e contribuir para a geração de emprego e renda; V - a previsão de áreas para habitação de interesse social por meio da demarcação de zonas especiais de interesse social e de outros instrumentos de política urbana, quando o uso habitacional for permitido; VI - definição de diretrizes e instrumentos específicos para proteção ambiental e do patrimônio histórico e cultural; e VII - definição de mecanismos para garantir a justa distribuição dos ônus e benefícios decorrentes do processo de urbanização do território de expansão urbana e a recuperação para a coletividade da valorização imobiliária resultante da ação do poder público (BRASIL, 2012, art. 26).

Embora trate-se de uma medida ainda recente, e pouco divulgada, e embora grande parte dos municípios já possuam atualmente seus perímetros urbanos com áreas bastante superiores ao razoável, tal medida pode ser considerada um primeiro avanço no sentido de reconhecer que o problema deve ser enfrentado de forma preventiva, estabelecendo claramente a relação de causalidade entre a questão da moradia e a da preservação do meio ambiente urbano. A realização desses planos pode constituir uma oportunidade para conter o processo de espraiamento excessivo da malha urbana que dificulta e encarece a implantação das redes de infraestrutura e serviços urbanos para todos os espaços da cidade. Essa também pode ser uma ferramenta oportuna para se buscar alternativas para a inclusão da população mais pobre de forma legal na cidade, possibilitando o combate ao fenômeno da ocupação irregular das áreas frágeis.

\section{Referências}

ALVES, H. P. da F. Vulnerabilidade socioambiental na metrópole paulistana: uma análise sociodemográfica das situações de sobreposição espacial de problemas e riscos sociais e ambientais. Revista Brasileira de Estudos Populacionais, v. 23, n. 1, p. 43-59, jan./jun 2006.

ALVIM, A. T. B. Direito à cidade e ao ambiente na metrópole contemporânea: o projeto Cantinho do Céu na Represa Billings, São Paulo. Arquitextos, v. 135, p. 1-22, mar. 2011. Disponível em: <http://www.vitruvius.com.br/ revistas/read/arquitextos/12.135/4015>. Acesso em: 4 maio 2013. 
ANCONA, A. L. APPs em áreas urbanas X direito à moradia. In: Seminário Nacional Sobre o Tratamento de Áreas de Preservação Permanente em Meio Urbano e Restrições Ambientais ao Parcelamento do Solo, 2007, São Paulo. Anais... São Paulo: FAUUSP, 2007. 1 CD-ROM.

BEZERRA, M. do C. de L.; CHAER, T. M. S. Regularização fundiária e os conflitos com as normas do Código Florestal para APP urbana. E-Metrópolis: Revista Eletrônica de Estudos Urbanos e Regionais, v. 3, n. 10, p. 26-36, set. 2012. Disponível em: <http://www.emetropolis.net/download/ edicoes/emetropolis_n10-2.pdf>. Acesso em: 6 mar. 2013.

BRASIL. Lei n. 9.785, de 29 de janeiro de 1999. Altera o Decreto-Lei n. 3.365, de 21 de junho de 1941 (desapropriação por utilidade pública) e as Leis n. 6.015, de 31 de dezembro de 1973 (registros públicos) e 6.766, de 19 de dezembro de 1979 (parcelamento do solo urbano). Diário Oficial [da] República Federativa do Brasil, Poder Legislativo, Brasília, DF, 30 jan. 1999. Disponível em: <http://www.planalto.gov.br/ccivil_03/leis/19785. htm>. Acesso em: 6 maio 2013.

BRASIL. Lei n. 10.257, de 10 de julho de 2001. Regulamenta os arts. 182 e 183 da Constituição Federal, estabelece diretrizes gerais da política urbana e dá outras providências. Diário Oficial [da] República Federativa do Brasil, Poder Legislativo, Brasília, DF, 11 jul. 2001. Disponível em: <http://www.planalto.gov.br/ccivil_03/ leis/LEIS_2001/L10257.htm> Acesso em: 4 maio 2013.

BRASIL. Lei n. 11.977, de 7 de julho de 2009. Dispõe sobre o Programa MinhaCasa, Minha Vida-PMCMV ea regularização fundiária de assentamentos localizados em áreas urbanas. Diário Oficial [da] República Federativa do Brasil, Poder Legislativo, Brasília, DF, 8 jul. 2009. Disponível em: <http:// www.planalto.gov.br/ccivil_03/_ato2007-2010/2009/ lei/l11977.htm>. Acesso em: 4 maio 2013.

BRASIL. Lei n. 12.608, de 10 de abril 2012. Institui a Política Nacional de Proteção e Defesa Civil - PNPDEC; dispõe sobre o Sistema Nacional de Proteção e Defesa Civil - SINPDEC e o Conselho Nacional de Proteção e Defesa Civil - CONPDEC; autoriza a criação de sistema de informações e monitoramento de desastres; altera as Leis n. 12.340, de 1 o de dezembro de 2010, 10.257, de 10 de julho de 2001, 6.766, de 19 de dezembro de 1979, 8.239, de 4 de outubro de 1991, e 9.394, de 20 de dezembro de 1996; e dá outras providências. Diário Oficial [da] República Federativa do Brasil, Poder Legislativo, Brasília, DF, 11 abril 2012. Disponível em: <http:// www.planalto.gov.br/ccivil_03/_Ato2011-2014/2012/ Lei/L12608.htm>. Acesso em: 11 jul. 2013.
CIDADE, L. C. F. Urbanização, ambiente, risco e vulnerabilidade em áreas urbanas: em busca de uma construção interdisciplinar. Cadernos Metrópole, v. 15, n. 29, p. 171-191, jan./jun. 2013.

COSTA, H. S. M. (Org.) Novas periferias metropolitanas - A expansão metropolitana em Belo Horizonte: dinâmica e especificidades do Eixo Sul. Belo Horizonte: C/ Arte, 2006.

DAVIS, M. Planeta favela. São Paulo: Boitempo, 2006.

DIÁRIO DO NORDESTE. Quintas do Lago: tranquilidade e natureza como diferenciais. Diário do Nordeste, Fortaleza, 4 abril 2006. Disponível em: <http://diariodonordeste.globo.com/materia.asp?codigo $=326796>$. Acesso em: 11 jul. 2013.

PREFEITURA MUNICIPAL DE EUSÉBIO. Plano Diretor Participativo do Eusébio: Produto III Leitura técnica. Eusébio: PME, 2008.

EVANS, P. (Ed.). Livable cities? Urban struggles for livelihood and sustainability. Berkeley: University of California Press, 2002.

FERNANDES, E. Proteção ambiental ou direito a moradia? Um falso conflito. In: FERNANDES, E.; ALFONSIN, B. (Org.). Direito urbanístico: estudos brasileiros e internacionais. Belo Horizonte: Del Rey, 2006. p. 356-358.

FREITAS, C. F. S. A produção desequilibrada do meio ambiente urbano de Fortaleza e o papel do movimento ambientalista. In: ENCONTRO NACIONAL DA ASSOCIAÇÃO NACIONAL DE PESQUISA E PÓS-GRADUAÇÃO EM AMBIENTE E SOCIEDADE, 2., 2004, Indaiatuba. Anais... Indaiatuba: ANPPAS, 2004.

FREITAS, C. F. S. Proteção ambiental e direito à cidade no processo de expansão urbana do Distrito Federal: até que ponto existe um conflito? 2009. $152 \mathrm{f}$. Tese (Doutorado em Arquitetura e Urbanismo) Universidade de Brasília, Brasília, 2009.

FREITAS, C.; PEQUENO, R. Produção habitacional na Região Metropolitana de Fortaleza na década de 2000: Avanços e Retrocessos. In: ENCONTRO NACIONAL DA ANPUR, 14., 2011, Rio de Janeiro. Anais... Rio de Janeiro: UFRJ, 2011.

FUNDAÇÃO JOÃO PINHEIRO. Deficit habitacional no Brasil. Disponível em: <http://www.fjp.mg.gov.br/index. php/produtos-e-servicos1/2598-deficit-habitacional-no-brasil-3>. Acesso em: 23 jan. 2014.

HARVEY, D. Justice nature and the geography of difference. Massachusetts: Blackwell, 1996. 
IBGE. Censo Demográfico 2010: Dados do universo. 2010. Disponível em: <http://downloads.ibge.gov.br/downloads_estatisticas.htm>. Acesso em: 11 jul. 2013.

MARTINS, M. L. R. Moradia e mananciais: tensão e diálogo na metrópole. São Paulo: FAUUSP; FAPESP, 2006.

MORETTI, R. Normas urbanísticas para habitação de interesse social: recomendações para elaboração. São Paulo: IPT, 1997.

MOTA, S. Urbanização e Meio Ambiente. Rio de Janeiro: ABES, 2003.

PINHO, A. V.; FREITAS, C. F. S. Ocupação ilegal de áreas urbanas frágeis, especulação imobiliária e exclusão sócio-espacial em Fortaleza. In: SEMINÁRIO NACIONAL SOBRE ÁREAS DE PRESERVAÇÃO PERMANENTE EM MEIO URBANO: ABORDAGENS CONFLITOS E PERSPECTIVAS NAS CIDADES BRASILEIRAS, 2., 2012, Natal. Anais... Natal: UFRN, 2012.

PREFEITURA MUNICIPAL DE FORTALEZA. Base de dados do Imposto de Transmissão de Bens Intervivos - ITBI. 2010. Secretaria das Finanças do Município. Dados não publicados.

PREFEITURA MUNICIPAL DE FORTALEZA. Plano Local de Habitação de Interesse Social. Fortaleza, 2011. (No prelo).

SANTOS Jr., O. A.; MONTANDON, D. T. (Org.). Os planos diretores municipais pós-estatuto da cidade: balanço crítico e perspectivas. Rio de Janeiro: Letra Capital; Observatório das Cidades; IPPUR; UFRJ, 2011.
SANTOS, R. F. do (Org.). Vulnerabilidade ambiental: desastres naturais ou fenômeno induzido? Brasília: MMA, 2007.

SINDICATO DA INDÚSTRIA DA CONSTRUÇÃO CIVIL DO ESTADO DO CEARÁ - SINDUSCON-CE. Relatório mensal Índice de Velocidade de Vendas. Disponível em: <http:// sindusconce.com/ivv.asp>. Acesso em: 23 jan. 2014.

SOUZA, M. S. N de. Diagnóstico geoambiental do município de Fortaleza: subsídios ao macrozoneamento ambiental e à revisão do Plano Diretor Participativo - PDPFOR. Fortaleza: Prefeitura Municipal de Fortaleza, 2009.

TORRES, H. G. Desigualdade ambiental na cidade de São Paulo. 1997. 286 f. Tese (Doutorado em Ciências Sociais) - Instituto de Filosofia e Ciências Humanas, Universidade Estadual de Campinas, Campinas, 1997.

Recebido: 16/02/2013

Received: 02/16/2013

Aprovado: 02/07/2013

Approved: 07/02/2012 